\title{
Pengaruh Jarak Nozzle dan Tekanan Gas pada Proses Pelapisan FeCrBMnSi dengan Metode Wire Arc Spray terhadap Ketahanan Thermal
}

\author{
Muhammad Suchaimi, Rochman Rochiem, dan Hariyati Purwaningsih \\ Jurusan Teknik Material dan Metalurgi, Fakultas Teknologi Industri, Institut Teknologi Sepuluh \\ Nopember (ITS) \\ Jl. Arief Rahman Hakim, Surabaya 60111 Indonesia \\ e-mail:m.suchaimi@gmail.com
}

\begin{abstract}
Abstrak--Low Temperature Hot Corrosion (LTHC) merupakan jenis hot corrosion yang terjadi pada temperatur 700$800^{\circ} \mathrm{C}$ dan biasa terjadi pada sudu-sudu turbin uap. Akibatnya material pada sudu turbin tersebut mengalami keretakan maupun penurunan efisiensi putaran. Perlindungan terhadap hot corrosion dengan cara memberikan penghalang antara substrat dengan lingkungan salah satunya menggunakan metode pelapisan permukaan logam yaitu wire arc spray. Penelitian ini bertujuan untuk menganalisis pengaruh jarak nozzle dan tekanan gas pada pelapisan FeCrBMnSi dengan metode wire arc spray terhadap ketahanan thermal. Dari parameter jarak nozzle dan tekanan gas yang digunakan, didapatkan parameter terbaik yaitu pada jarak $400 \mathrm{~mm}$ dan tekanan gas 3 bar yang mempunyai kekuatan lekat sebesar 22,58 MPa dengan persentase porositas 5,93\% dan nilai kekasaran permukaan sebesar $16,36 \mu \mathrm{m}$. Sedangkan pada pengujian thermal cycle yang dilakukan dengan cara pemanasan dan pendinginan secara kontinyu, pada permukaan coating terbentuk senyawa oksida $\mathrm{Fe}_{3} \mathrm{O}_{4}$ yang menyebabkan perambatan retak dan delaminasi. Selain itu kekerasan lapisan coating meningkat akibat adanya senyawa precipitate boride $\left(\mathrm{Fe}_{9} \mathrm{~B}\right)_{0,2}$.
\end{abstract}

Kata Kunci : Coating, Wire Arc Spray, FeCrBMnSi, Jarak Nozzle, Tekanan Gas, Ketahanan Thermal

\section{PENDAHULUAN}

Turbin uap merupakan suatu penggerak mula yang mengubah energi potensial uap menjadi energi kinetik dan selanjutnya diubah menjadi energi mekanik dalam bentuk putaran poros turbin. Poros turbin, lansung atau dengan bantuan roda gigi reduksi, dihubungkan dengan mekanisme yang akan digerakkan. Turbin uap dapat digunakan pada berbagai bidang seperti pada bidang industri, untuk pembangkit tenaga listrik dan untuk transportasi. Keuntungan utama menggunakan turbin uap yaitu dapat menghasilkan energi mekanik yang maksimal untuk menggerakkan generator listrik, namun di sisi lain ada biaya tambahan yang diperlukan untuk perawatan yang lebih besar. Tanpa adanya perawatan yang baik pada turbin uap, maka akan menimbulkan masalah-masalah yang berkaitan dengan kinerja dan kualitas turbin uap, bahkan resiko keselamatan sangat mungkin terjadi. Karena turbin uap bekerja pada tekanan dan temperatur yang tinggi. Salah satu komponen pada turbin uap yang sering mengalami kegagalan atau kerusakan yaitu sudu-sudu turbin. Kerusakan tersebut biasanya disebabkan oleh erosion, hot corrosion, fouling dan high cycle fatigue.

Hot Corrosion merupakan jenis korosi temperatur tinggi yang terjadi pada sudu-sudu turbin uap. Ada dua jenis hot corrosion, yaitu high temperature hot corrosion (HTHC) yang terjadi pada temperatur $825^{\circ} \mathrm{C}-950^{\circ} \mathrm{C}$ dan low temperature hot corrosion (LTHC) yang terjadi pada temperatur $700^{\circ} \mathrm{C}-$ $800^{\circ} \mathrm{C}$. Jenis korosi ini disebabkan adanya kondensasi dari zat kimia yang bekerja pada benda yang bersifat korosif. Korosi dapat menimbulkan berbagai macam kerugian diantaranya adalah berupa biaya perawatan dan biaya penggantian material. Berbagai cara telah dilakukan untuk mengendalikan laju korosi yaitu dengan mengurangi gas-gas yang bersifat korosif, mencegah terbentuknya kerak dan deposit pada sudu-sudu turbin serta memberi lapisan pelindung. Memberi lapisan pelindung dilakukan dengan cara memutus rantai korosi dengan melindungi logam sehingga konduktor atau kontak metalik tidak berfungsi sehingga elektron tidak bisa mengalir dan korosi terhambat. Sudah banyak jenis bahan pelapisan untuk menanggulangi terjadinya korosi, salah satunya dengan pelapisan logam. Logam metalik adalah penghalang yang berkesinambungan antara permukaan logam dan lingkungan.

Pelapisan permukaan logam adalah suatu cara yang dilakukan untuk memberikan sifat ketahanan thermal dan hot corrosion pada suatu permukaan benda kerja, dimana diharapkan benda tersebut akan mengalami perbaikan baik dalam hal struktur mikro maupun ketahanannya, dan tidak menutup kemungkinan pula terjadi perbaikan terhadap sifat fisiknya. Pelapisan logam merupakan bagian akhir dari proses produksi suatu produk maupun bagian dari proses maintenance atau pemeliharaan terhadap suatu komponen atau benda kerja . Salah satu metode pelapisan permukaan logam yaitu metode arc spray. Metode ini merupakan salah satu jenis dari thermal spray. Arc spray coating merupakan salah satu teknik pelapisan logam (coating) dalam bentuk kawat. Busur antara dua kawat dalam proses arc spray coating ini digunakan untuk mencairkan bahan pelapis. Dalam arc spray coating tekanan gas sangat berpengaruh terhadap kualitas dari hasil coating. Proses ini akan menentukan karakteristik permukaan akhir material substrat.

Dalam penelitian ini dilakukan variasi jarak nozzle dan tekanan gas ketika proses pelapisan FeCrBMnSi coating untuk memperoleh parameter yang paling optimal terhadap sifat 
korosi dan ketahananya pada temperatur tinggi.

\section{METODE PENELITIAN}

\section{A. Preparasi Spesimen VCL 140}

Spesimen dipotong menurut dimensi yang ditentukan sebanyak 8 buah. Melakukan proses abrasive grit blasting menggunakan aluminum oxide 24 mesh dengan tekanan sebesar 7 bar dan jarak nozzle $100 \mathrm{~mm}$. Hal ini bertujuan agar permukaan spesimen menjadi kasar serta untuk meningkatkan ikatan mekanik antara material substrat dengan pelapisnya.

\section{B. Proses Pelapisan}

Melalukan spraying bond coat $\mathrm{NiAl}$ dengan tekanan 4 bar dan jarak nozzle $200 \mathrm{~mm}$. Bond coat ini berfungsi sebagai lapisan perekat antara substrat dengan lapisan top coat. Selanjutnya melakukan spraying 95 MXC wire dengan sudut $90^{\circ}$, dengan variasi jarak dan tekanan gas yang digunakan. (variasi jarak yang digunakan adalah $100 \mathrm{~mm}, 200 \mathrm{~mm}, 300$ $\mathrm{mm}$ dan $400 \mathrm{~mm}$, sedangkan tekanan yang digunakan adalah 3 bar dan 4 bar).

\section{Pengujian Kekasaran Permukaan}

Pengujian ini dilakukan untuk mengetahui nilai kekasaran permukaan sampel yang telah dicoating. Pengujian ini menggunakan 8 sampel dengan ukuran $1.5 \mathrm{~cm}$ x $1.5 \mathrm{~cm}$. Pengujian ini menggunakan alat uji surface roughness tester SJ-301 user's manual Mitutoyu dengan standard JIS20 (dalam satuan mikro meter).

\section{Pengujian SEM}

Pengujian Scanning Electron Microscopy (SEM) menggunakan mesin merek FEI Inspect S-50. Pengujian ini dilakukan untuk mengetahui morfologi permukaan dan ketebalan lapisan dari penampang substrat VCL 140 setelah mengalami proses abrasive grit blasting, dan kemudian dilapisi bond coat serta top coat.

\section{E. Pengujian XRD}

$X$-Ray Difraction adalah pengujian yang digunakan untuk mengetahui unsur dan senyawa yang terbentuk substrat dan hasil coating. Data hasil XRD berupa grafik dengan puncak internsitas terhadap 20. Data XRD ini digunakan untuk perhitungan komposisi unsur dan senyawa. Pengujian XRD ini menggunakan alat merk Xper pro panlythical.

\section{F. Pengujian Thermal Cycle}

Pengujian thermal cycle ini digunakan untuk mengukur massa yang hilang, morfologi permukaan coating, dan senyawa yang terbentuk ketika dipanaskan dari temperatur kamar sampai temperatur tertentu yang diinginkan. Analisis ini digunakan untuk mengetahui perilaku dan kestabilan termal dari material. Pengujian thermal cycle menggunakan mesin muffle furnace dengan heating rate sekitar $30^{\circ} \mathrm{C} /$ menit dan temperatur pemanasannya dari $25-600^{\circ} \mathrm{C}$ dalam keadaan vacum.

\section{G. Pengujian Pull Off Bonding}

Pengujian ini dilakukan untuk mengetahui daya lekat coating terhadap substratnya. Pengujian ini menggunakan lem Araldite yang berfungsi sebagai perekat antara pin dengan spesimen yang akan diuji. Pengujian akan berhenti ketika lem sudah terlepas dari specimen, dengan menarik sebagian permukaan coating. Nilai dari kelekatan akan ditunjukkan dari alat dalam satuan MPa.

\section{H. Pengujian Microhardness Vickers}

Pengujian ini dilakukan untuk mengetahui distribusi kekerasan fasa pada lapisan coating dengan kondisi sebelum dan setelah perlakuan thermal cycle. Pengujian ini menggunakan mesin microhardness vickers digital.

\section{HASIL DAN PEMBAHASAN}

\section{A. Pengujian SEM}

Pengamatan terhadap morfologi permukaan hasil coating FeCrBMnSi dilakukan dengan pengujian Scanning Electron Microscope (SEM) perbesaran perbesaran 1000x pada Gambar 2. Spesimen yang diamati terdiri dari variasi $100 \mathrm{~mm} ; 3 \mathrm{bar}$, $100 \mathrm{~mm} ; 4$ bar, $200 \mathrm{~mm} ; 3$ bar, $200 \mathrm{~mm} ; 4$ bar, $300 \mathrm{~mm} ; 3$ bar, $300 \mathrm{~mm}$; 4 bar, $400 \mathrm{~mm} ; 3$ bar, dan 400 mm; 4 bar.
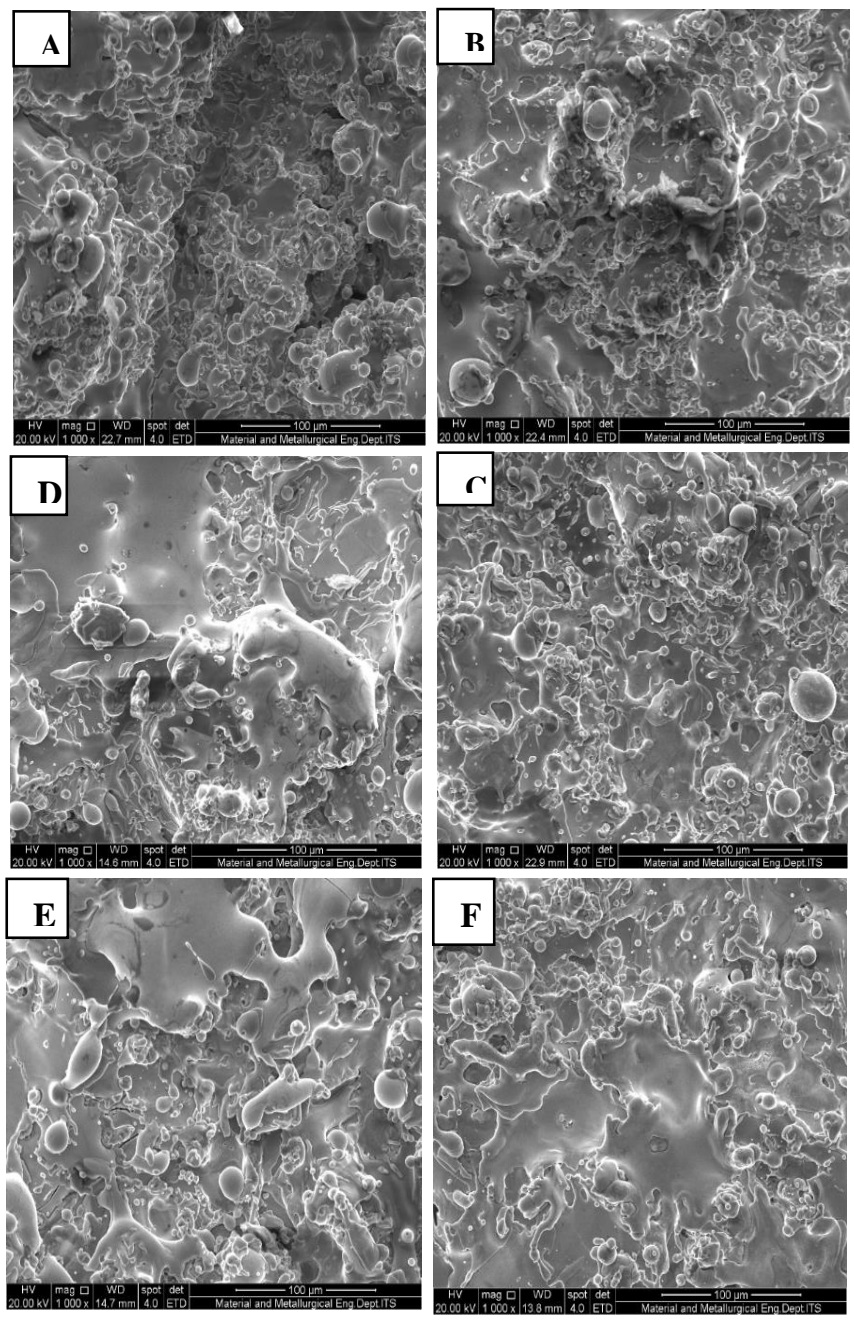

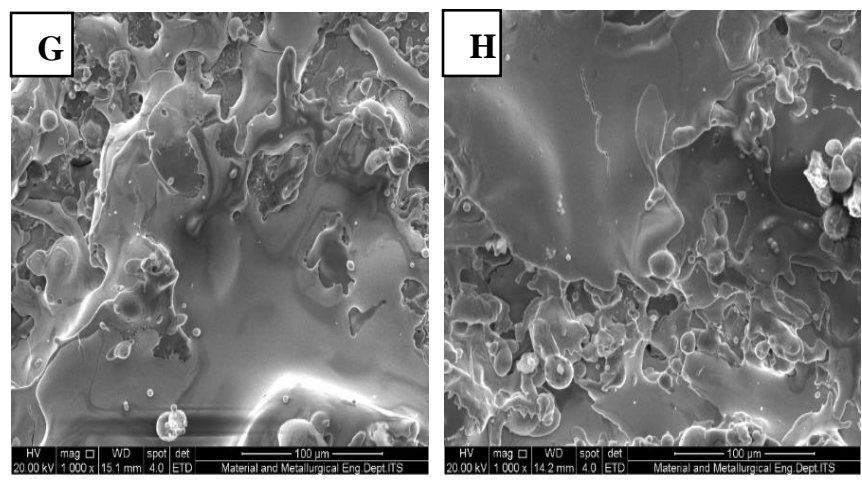

Gambar 1. Permukaan Spesimen Coating Perbesaran 1000x dengan Variasi (a) $100 ; 3$ (b) $100 ; 4$ (c) $200 ; 3$ (d) $200 ; 4$ (e) $300 ; 3$ (f) $300 ; 4$ (g) 400;3 (h) 400;4

Pada Gambar 1 menginformasikan bahwa semakin dekat jarak nozzle yang digunakan menghasilkan permukaan yang kurang rata dan halus. Hal ini disebabkan karena partikelpartikel belum meleleh secara sempurna, sehingga ketika mencapai permukaan substrat bentuk partikel tersebut masih bulat. Bulatnya bentuk partikel bisa menghasilkan rongga pada permukaan hasil coating sehingga nilai kekasaran dan porositasnya akan semakin besar [1]. Sedangkan dengan meningkatnya tekanan gas yang digunakan maka partikelpartikel yang terdapat di permukaan substrat mampu meleleh secara sempurna menghasilkan coating yang lebih baik. Hal ini disebabkan oleh meningkatnya kecepatan impact dari lelehan partikel yang lebih kecil ke permukaan substrat seiring dengan meningkatnya tekanan gas yang digunakan. Sehingga mampu meminimalisir rongga yang terbentuk antara partikel-partikel tersebut [2].

\section{B. Pengujian $X R D$}

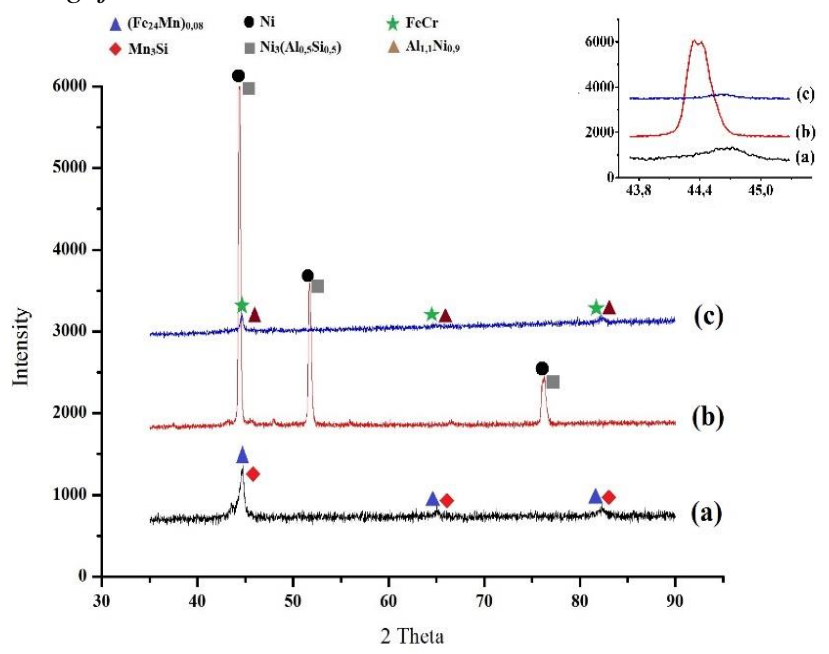

Gambar 2. Hasil XRD (a) Spesimen VCL 140, (b) Bond Coat dan (c) AsReceived Coating

Gambar 2 merupakan hasil pengujian XRD terhadap spesimen substrat VCL 140, hasil bond coat dan as-received coating. Pada material substrat menunjukkan pola XRD yang mempunyai tiga puncak difraksi pada $2 \theta=44,7416^{\circ} ; 65,0810^{\circ}$ dan $82,4353^{\circ}$, yang mengindikasikan terbentuknya fasa kristalin diantaranya terdapat senyawa paduan $\left(\mathrm{Fe}_{24} \mathrm{Mn}\right)_{0,08}$ dan $\mathrm{Mn}_{3} \mathrm{Si}$. Senyawa paduan $\left(\mathrm{Fe}_{24} \mathrm{Mn}\right)_{0,08}$ atau ferro manganese mampu meningkatkan sifat mekanik material dan ketahanan korosi [4]. Sedangkan senyawa paduan $\mathrm{Mn}_{3} \mathrm{Si}$ merupakan senyawa yang memberikan pengaruh sifat magnetik terhadap material VCL 140 [5]. Dengan demikian, dengan adanya kedua senyawa paduan tersebut memberikan keuntungan terutama dalam hal aplikasi pelapisan logam.

Pada pola XRD terhadap spesimen hasil bond coat menunjukkan bahwa terdapat 3 puncak difraksi pada $2 \theta=$ $44,3145^{\circ} ; \quad 44,4449^{\circ} ; 51,6314^{\circ} ; 51,8247^{\circ} ; 76,0573^{\circ}$ dan $76,3296^{\circ}$, yang mengindikasikan terbentuknya fasa kristalin diantaranya terdapat senyawa paduan $\mathrm{Ni}$ dan $\mathrm{Ni}_{3}\left(\mathrm{Al}_{0,5} \mathrm{Si}_{0,5}\right)$. Dengan adanya $\mathrm{Ni}$, material tersebut mempunyai kekuatan dan ketahanan korosi pada temperatur tinggi [6]. Sedangkan senyawa paduan $\mathrm{Ni}_{3}\left(\mathrm{Al}_{0,5} \mathrm{Si}_{0,5}\right)$ merupakan senyawa paduan hasil reaksi antara unsur $\mathrm{Ni}$ dan $\mathrm{Al}$ yang membentuk senyawa nickel aluminide. Senyawa tersebut mampu meningkatkan kekuatan adhesi antara material substrat dan coating [7].

Sedangkan pada Pola XRD material as-received coating menunjukkan bahwa adanya puncak difraksi pada $2 \theta=$ $44,6492^{\circ} ; 64,921^{\circ}$ dan $82,3322^{\circ}$, yang mengindikasikan adanya senyawa paduan $\mathrm{FeCr}$, dan $\mathrm{Al}_{1,1} \mathrm{Ni}_{0,9}$. Fasa intermetalik $\mathrm{Fe}-\mathrm{Cr}$ tidak memiliki kekerasan yang cukup tinggi, namun berpengaruh terhadap ketangguhan lapisan coating, sehingga tidak mudah terkelupas saat menerima beban kejut [8]. Sedangkan pada hasil XRD as-received coating terbentuk senyawa paduan $\mathrm{Al}_{1,1} \mathrm{Ni}_{0,9}$. Hal ini menandakan bahwa senyawa paduan yang terbentuk pada material bond coat dan asreceived coating mengalami proses difusi dan berikatan dengan baik, sehingga meningkatkan kekuatan adhesi antara material bond coat dan as-received coating.

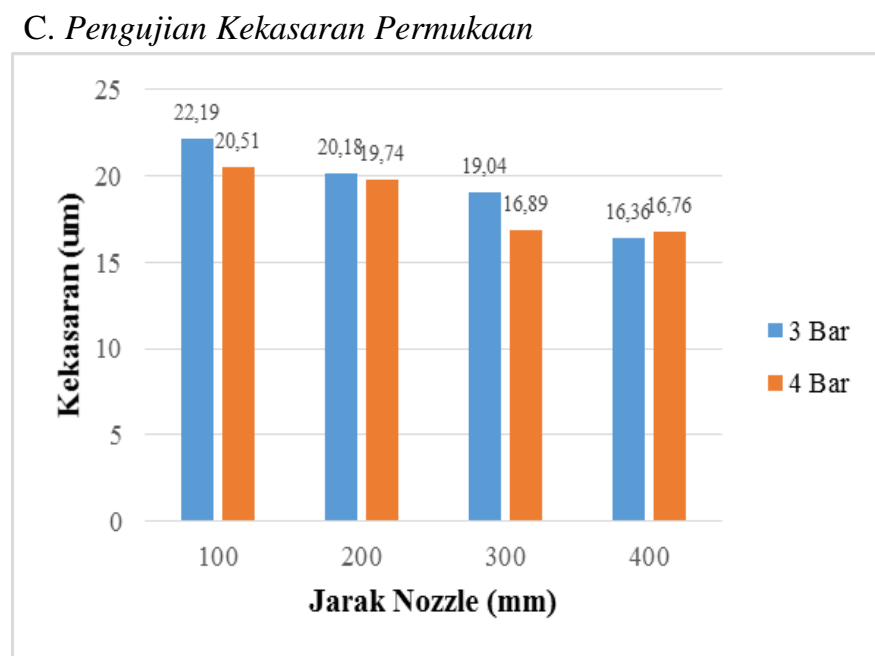

Gambar 3. Grafik Kekasaran Permukaan

Gambar 3 menunjukkan kekasaran permukaan pada hasil coating dengan jarak nozzle $400 \mathrm{~mm} ; 3$ bar memiliki nilai kekasaran permukaan paling kecil yaitu $16,36 \mu \mathrm{m}$. Sedangkan nilai kekasaran permukaan paling besar dimiliki permukaan 
hasil coating dengan jarak nozzle $100 \mathrm{~mm}$ dan tekanan gas 3 bar yaitu sebesar 22,19 $\mu \mathrm{m}$. Dari hasil yang ada dengan meningkatnya tekanan gas pada proses wire arc spray menurunkan kekasaran permukaan hasil coating. Dengan meningkatknya tekanan gas pada proses wire arc spray mempercepat kecepatan impact dari lelehan partikelnya yang lebih kecil ke substrat. Sehingga menyebabkan partikel-partikel tersebut melebur secara sempurna dan rongga yang terbentuk antar partikel menjadi sedikit [2].

\section{Pengujian Porositas}

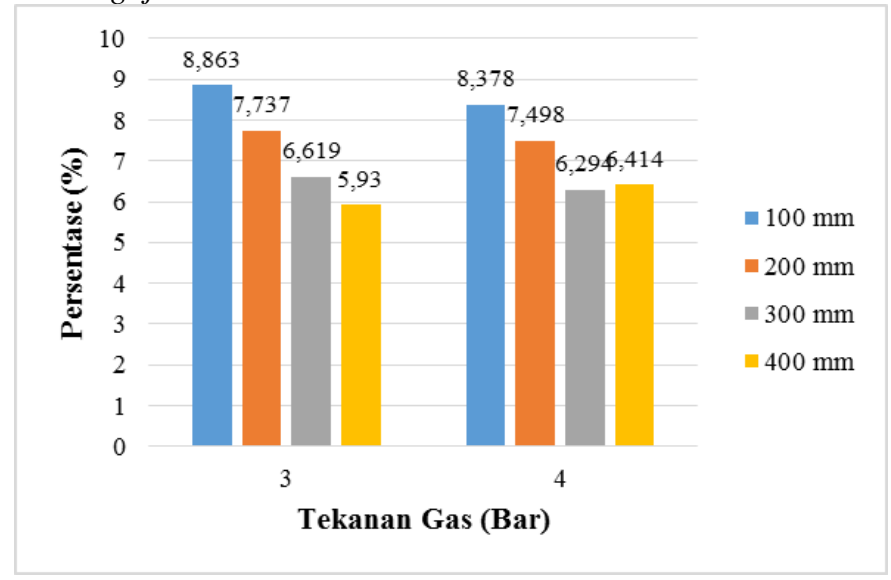

Gambar 4. Grafik Persentase Porositas

Gambar 4 merupakan grafik persentase porositas. Pada gambar tersebut menginformasikan bahwa semakin besar jarak nozzle dan tekanan gas yang digunakan mengakibatkan penurunan porositas. Hal ini dikarenakan jarak nozzle dan tekanan gas memberikan pengaruh terhadap ukuran splat. Semakin besar jarak nozzle dan tingginya tekanan gas memperkecil ukuran splat [3]. Selain itu dengan meningkatnya tekanan gas yang digunakan mempercepat kecepatan impact dari lelehan partikelnya yang lebih kecil ke permukaan substrat. Sehingga menyebabkan partikel-partikel tersebut melebur secara sempurna dan rongga yang terbentuk antar partikel menjadi sedikit [2].

\section{E. Pengujian Pull Off Bonding}

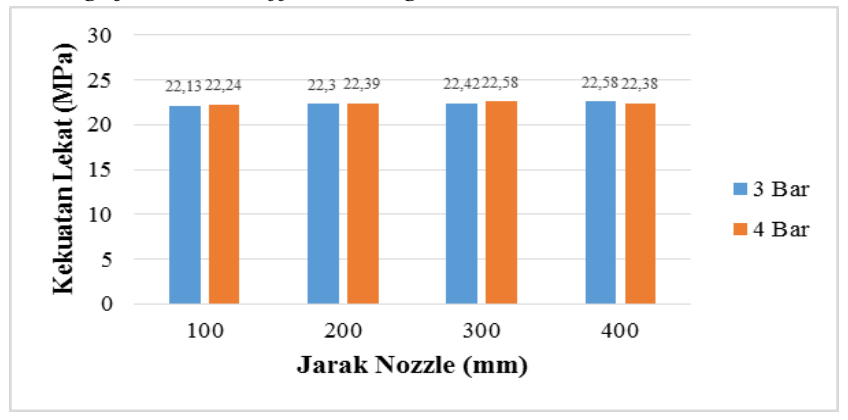

Gambar 5. Grafik Pull Off Bonding

Gambar 5 menunjukkan bahwa spesimen yang memiliki kekuatan lekat tertinggi adalah spesimen dengan variasi 300 $\mathrm{mm} ; 4$ bar dan $400 \mathrm{~mm} ; 3$ bar yaitu 22,58 MPa dan spesimen yang memiliki kekuatan terendah yaitu spesimen dengan jarak $100 \mathrm{~mm}$ dan tekanan gas 3 sebesar 22,13 MPa.

Dari data tersebut diketahui bahwa pada jarak $100 \mathrm{~mm}$ memiliki ukuran ketebalan terbesar pada hasil coating, sehingga daya lekatnya pun menurun dibandingkan denga jarak $200 \mathrm{~mm}, 300 \mathrm{~mm}$ dan $400 \mathrm{~mm}$. Hal ini dikarenakan dengan meningkatnya ketebalan maka menimbulkan tegangan permukaan yang besar antara permukaan substrat dengan hasil coating [9]. Selain itu, pada penelitian yang lain dijelaskan bahwa porositas dalam jumlah yang rendah dapat memperbaiki sifat kerapatan coating dan menghasilkan ikatan yang baik antara substrat dengan lapisan coating. Besarnya tingkat porositas meningkatkan rongga permukaan antara coating dengan substrat sehingga menurunkan tingkat kelekatan antara permukaan substrat dengan lapisan coating [10].

\section{F. Pengujian Thermal Cycle}

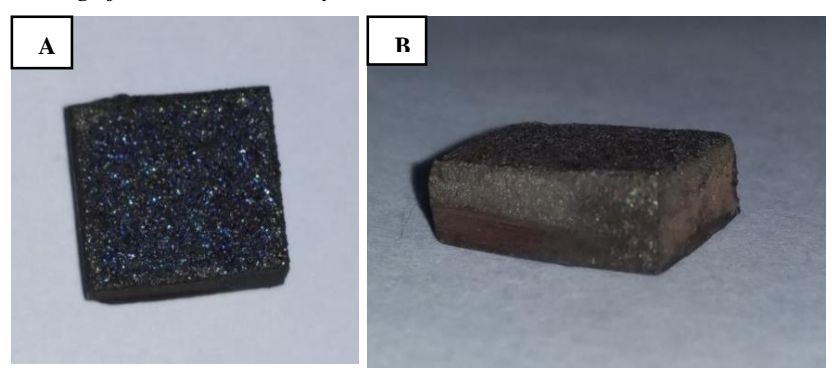

Gambar 6. Hasil Pengamatan Makro Spesimen Setelah 50 Cycle (a) Tampak Permukaan Hasil Coating (b) Tampak Cross Section

Hasil pengamatan secara visual pada Gambar 6 (a) merupakan spesimen yang mengalami perlakuan 50 cycle menunjukkan bahwa permukaan hasil coating mulai berwarna kehitaman, sedikit terkorosi serta penurunan kekasaran. Hal ini disebabkan adanya proses perlakuan thermal cycle pada temperatur $600^{\circ} \mathrm{C}$ serta waktu pendinginan di udara bebas selama 30 menit.

Gambar 9 (b) merupakan bagian cross section spesimen terutama bagian substrat menunjukkan bahwa bagian tersebut tidak mengalami pelelehan material maupun keretakan ( $\mathrm{crack}$ ) setelah perlakuan thermal cycle. Hal ini disebabkan adanya unsur $\mathrm{Cr}$ dan $\mathrm{Mo}$ yang memberikan pengaruh sifat ketahanan terhadap temperatur tinggi [6].

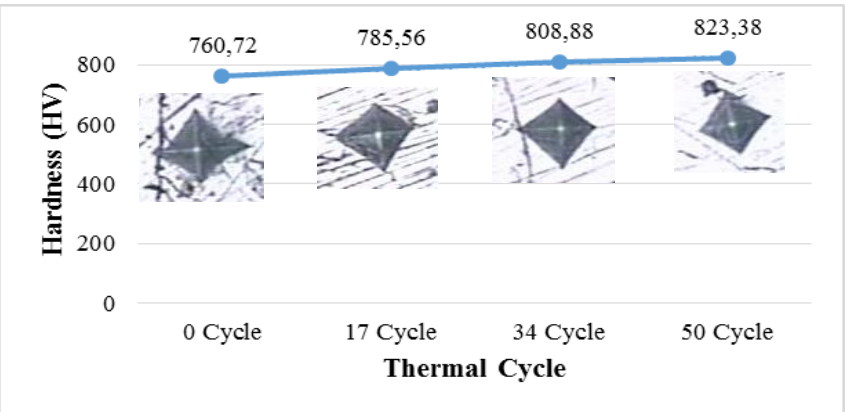

Gambar 7. Grafik Microhardness Vicker Spesimen Sebelum dan Setelah Thermal Cycle

Dari Gambar 7 terlihat bahwa dengan peningkatan perlakuan thermal cycle membuat hasil coating meningkat nilai kekerasannya. Hal ini dikarenakan dua hal : (1) Penurunan tensile residual stress pada hasil coating, dengan residual 
stress menurun maka hasil coating tersebut mampu menahan beban sebesar tensile residual stress yang turun ditambah dengan beban yang mampu diterima hasil coating tersebut, (2) Proses kristalisasi dari fasa amorfus sehingga terbentuk fasa fine crystalline yang seragam (uniformity of grain size) [11].

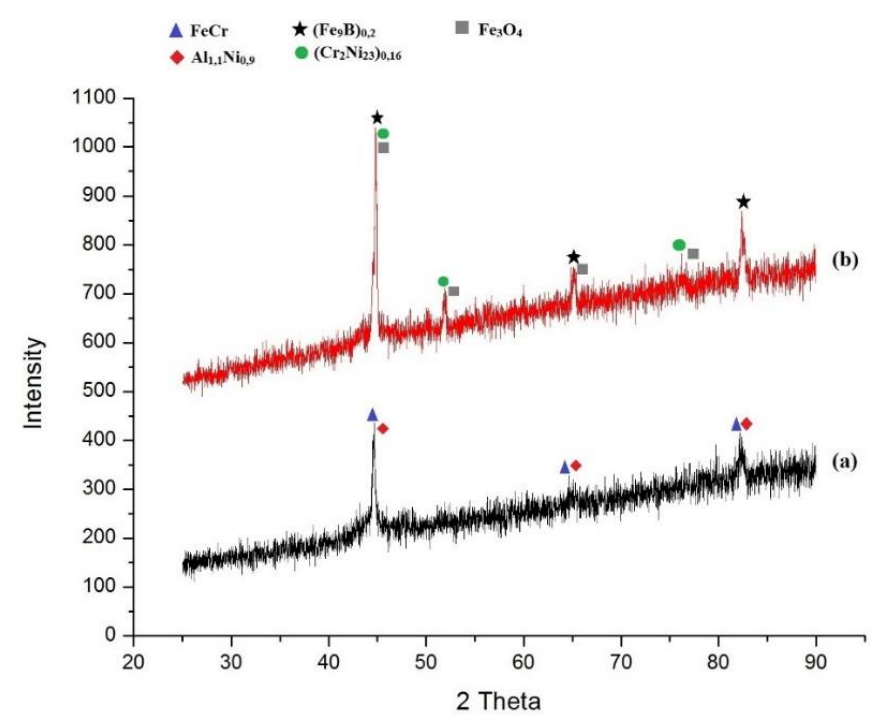

Gambar 8. Hasil XRD Spesimen (a) As-Received Coating dan (b) 50 Cycle

Gambar 8 merupakan perbandingan hasil pengujian XRD terhadap spesimen (a) as-reeceived coating dan (b) perlakuan thermal cycle dengan jumlah 50 cycle. Pada profil single peak yang paling tajam terhadap kedua spesimeen tersebut mengalami pergeseran posisi 2 theta, sehingga menyebabkan terbentuknya senyawa baru akibat adanya perlakuan thermal cycle. Perubahan posisi 2 theta menjadi $44,8200^{\circ} ; 51,8565^{\circ}$; $65,1849^{\circ} ; 76,3376^{\circ}$ dan $82,3604^{\circ}$. Beberapa senyawa yang terindentifikasi yaitu senyawa paduan $\left(\mathrm{Fe}_{9} \mathrm{~B}\right)_{0,2} ;\left(\mathrm{Cr}_{2} \mathrm{Ni}_{23}\right)_{0,16}$ dan senyawa oksida $\mathrm{Fe}_{3} \mathrm{O}_{4}$. Senyawa paduan $\left(\mathrm{Fe}_{9} \mathrm{~B}\right)_{0,2}$ atau precipitate boride ini memberikan pengaruh terhadap peningkatan kekerasan lapisan coating seiring dengan meningkatnya jumlah cycle yang diujikan [12].

Sedangkan senyawa paduan $\left(\mathrm{Cr}_{2} \mathrm{Ni}_{23}\right)_{0,16}$ atau chromium nickel terbentuk akibat adanya perlakuan thermal cycle terhadap spesimen. Dimungkinkan terjadinya pengelupasan lapisan coating di beberapa area, sehingga senyawa paduan dalam material bond coat dan top coat berdifusi membentuk senyawa paduan baru yang salah satunya $\left(\mathrm{Cr}_{2} \mathrm{Ni}_{23}\right)_{0,16}$ atau chromium nickel.

Senyawa oksida $\mathrm{Fe}_{3} \mathrm{O}_{4}$ terbentuk akibat adanya fenomena Pilling-Bedworth Ratio (PBR) yang tinggi, dimana disebabkan oleh perlakuan thermal cycle [11]. Senyawa oksida $\mathrm{Fe}_{3} \mathrm{O}_{4}$ membentuk lapisan tipis atau thin film dimana terdapat oksida yang terperangkap di dalam partikel thin film tersebut.

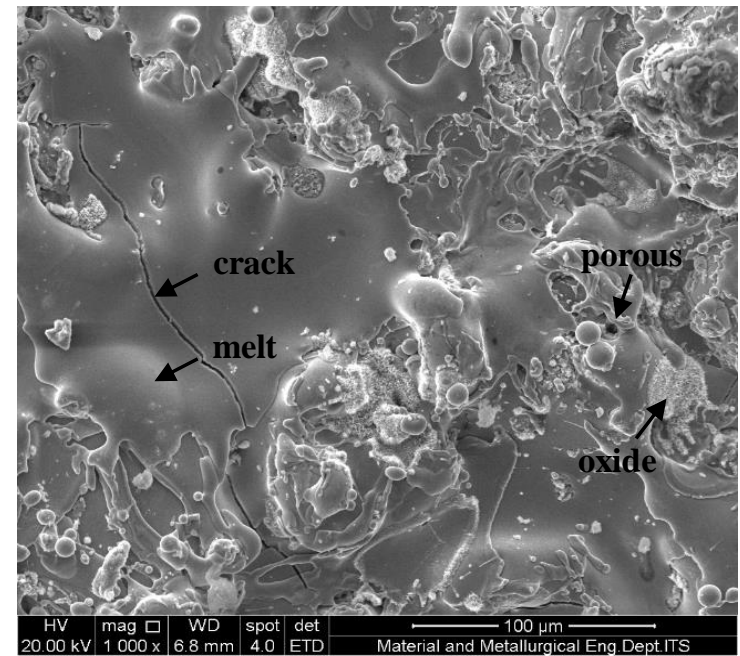

\begin{tabular}{|c|c|c|c|c|c|}
\hline Keterangan & $\mathbf{F e}(\boldsymbol{\%})$ & $\mathbf{C r}(\boldsymbol{\%})$ & $\begin{array}{c}\text { Mn } \\
(\boldsymbol{\%})\end{array}$ & $\begin{array}{c}\text { Si } \\
(\boldsymbol{\%})\end{array}$ & $\mathbf{O}(\boldsymbol{\%})$ \\
\hline (a) Melt & 68,9 & 26,77 & 0,43 & 1,38 & 2,53 \\
\hline (b) Oxide & 37,17 & 41,34 & 2,03 & - & 19,46 \\
\hline
\end{tabular}

Gambar 9. Hasil Pengujian SEM/EDS Setelah 50 Cycle dengan Kondisi (a) Daerah Melt dan (b) Daerah Oxide

Gambar 9 merupakan hasil pengujian SEM/EDS dengan perbesaran 1000x terhadap morfologi permukaan hasil coating setelah perlakuan thermal cycle pada 50 cycle. Dari hasil tersebut menunjukkan jumlah partikel-partikel yang meleleh lebih banyak bila dibandingkan dengan sebelum perlakuan. Sedangkan partikel-partikel yang tidak meleleh jauh berkurang. Tetapi pada morfologi permukaan muncul retak halus (soft crack) membentuk jalur yang cukup panjang.

Dari hasil EDS menunjukkan bahwa pada daerah yang meleleh (melt) secara sempurna mempunyai komposisi yang sama dengan sampel sebelum perlakuan. Tetapi komposisi masing-masing unsur tersebut mengalami perubahan. Sedangkan pada daerah yang teroksidasi (oxide) mempunyai kandungan oksida yang cukup tinggi sekitar 19\%. Terbukti dengan hasil pengujian XRD teridentifikasi senyawa oksida yaitu $\mathrm{Fe}_{3} \mathrm{O}_{4}$.

Senyawa oksida tersebut terbentuk akibat adanya fenomena Pilling Bedworth Ratio (PBR) yang tinggi [11]. Secara morfologi dimungkinkan senyawa oksida $\mathrm{Fe}_{3} \mathrm{O}_{4}$ membentuk lapisan tipis atau thin film dimana terdapat oksida yang terjebak di dalam partikel thin film tersebut. Dengan adanya oksida yang terperangkap, mampu menghasilkan tegangan dalam atau internal stress dan diikuti dengan adanya pertumbuhan crack serta delamination. Crack dan delamination memberikan ruang terhadap oksigen untuk berpenetrasi ke dalam lapisan coating [11]. 


\section{KESIMPULAN}

Berdasarkan data penelitian dan analisis yang telah dilakukan dapat ditarik beberapa kesimpulan sebagai berikut :

1. Pada variasi jarak nozzle sebesar $400 \mathrm{~mm}$ dan tekanan gas sebesar 3 bar menghasilkan nilai kekuatan lekat terbesar 22,58 $\mathrm{MPa}$ dengan persentase porositas $5,93 \%$ dan tingkat kekasaran permukaan $16,36 \mu \mathrm{m}$.

2. Kondisi spesimen setelah perlakuan thermal cycle ke-50 tidak mengalami penurunan massa yang signifikan. Penurunan massa disebabkan oleh penurunan kekasaran partikel coating tetapi material substrat tidak mengalami pelelehan.

3. Perlakuan thermal cycle hingga cycle ke-50 berpengaruh terhadap peningkatan kekasaran permukaan hasil coating. Hal ini dikarenakan terdapat senyawa baru yang terbentuk yaitu $\left(\mathrm{Fe}_{9} \mathrm{~B}\right)_{0,2}$ atau precipitate boride.

4. Kondisi permukaan hasil coating setelah perlakuan thermal cycle ke-50 terdapat perambatan retak dan delaminasi akibat senyawa oksida $\mathrm{Fe}_{3} \mathrm{O}_{4}$.

\section{DAFTAR PUSTAKA}

[1] Sarikaya, Ozkan. 2005. Effect of the Substrate Temperature SS304L On Properties of Plasma Sprayed $\mathrm{Al}_{2} \mathrm{O}_{3}$ Coatings. Materials and Design 26, 53-57.

[2] Wang, X., Heberlein, J., Pfender, E., Gerberich, W., Effect of Nozzle Configuration, Gas Pressure, and Gas Type on Coating Properties in Wire Arc Spray, JTTEE5 8:565-575 (1999).

[3] Daengmool, Reungruthai, Sitichai Wirijanupathum, Sukanda J., Apicat Sopadang. Effect of Spray Parameter on Stainless Steel Arc Sprayed Coating. MP03 (2006).

[4] Dybkov. 2016. Basic of Formation of Iron Boride Coatings. Department of Physical Chemistry of Inorganic Materials, Institute of Problems of Materials Science, National Academy of Sciences of Ukraine : Ukraine.

[5] Kaufmann, E.N. 2003. Characterization Of Materials: Volumes 1 and 2. Hoboken: John Wiley \& Sons.

[6] Suherman, Wahid. 1999. Ilmu Logam 2. Surabaya : ITS Press.

[7] Chaitanya. 2007. Processing and Characterization of Nickel-Aluminide Coating On Metal Substrates. Master of Technology In Mechanical Engineering Thesis. National Institute of Technology, Roukela.

[8] Yuping Wu, Pinghua, Lin. Guozhie Xie. 2006. Formation of Amorphous and Nanocrystalline Phase in High VelocityOxy-Fuel Thermally Sprayed a Fe-Cr-B-Mn-Si Alloy. Materials Science Engineering. A 430 34-39.

[9] Antunes, Jose Fernando, Brito, Vinisius Ribeiro dos Santos de Sa, Bastos, Ivan Napoleao, Costa, Hector Reynaldo Meneses. 2013. Characterization of $\mathrm{FeCr}$ and $\mathrm{FeCoCr}$ alloy Coatings of Carbon Steels for Marine Environment Applications. Applied Adhesion Science 2013 $1: 3$.

[10] Fernando, Jose Antunes. 2013. Characterization of $\mathrm{FeCr}$ and $\mathrm{FeCoCr}$ alloy coatings of carbon steels for marine environment applications. Adhesion Science, 1:3.

[11] Ran, Li. 2013. Microstructure and High-Temperature Oxidation Behavior of Wire-Arc Sprayed Fe Based Coating. Beijing University of Technology. Beijing. China.

[12] Zheng, Z.B, Zheng, Y.G, Sun, W.H. 2015. Effect of Heat Treatment On The Structure, Cavitation Erosion and Erosion Corrosion Behaviour of $\mathrm{Fe}$-Based Amorphous Coating. Tribology International Author's Manuscript. 